\title{
Investigations on Role of Stomata in Development of Citrus Canker caused by Xanthomonas axonopodis pv. citri
}

\author{
R. R. Jadhav*, K. T. Apet and D. S. Kadam \\ Department of Plant Pathology, Vasantrao Naik Marathwada Krishi Vidyapeeth, \\ Parbhani, M.S., India \\ *Corresponding author
}

\section{Keywords}

Bacterial canker, Acid Lime, Stomata, Incubation period, PDI

\section{Article Info}

Accepted:

25 November 2020 Available Online: 10 December 2020
Stomata plays vital role for entry of plant pathogens. Plant pathogens like bacteria, viruses enter through stomata. In citrus also the stomata plays important role in infection of bacterial canker caused by Xanthomonas axonopodis pv. citri. Studies to investigate the role of stomata in bacterial canker infection were conducted under screen house condition on different stomata aspects like count, size (length and breadth) and pore size in different six different citrus genotypes. The observations were recorded on per cent disease intensity and incubation period. These observations were correlated with stomata factors. The stomata size, pore size and frequency were positively correlated and increased the per cent disease intensity. There was negative correlation between stomata factors and incubation period. Maximum ' $r$ ' value was observed in positive correlated stomata pore size and per cent disease intensity $(0.768)$ followed by stomata width (0.764) and stomata length $(0.714)$ whereas; minimum ' $r$ ' value observed in stomata frequency $(0.230)$ which found positively non significant with per cent disease intensity. Highly significant but negative correlations were observed between stomata factors with incubation period. However, maximum ' $r$ ' value was observed in negative correlation between stomata pore size and per cent disease intensity $(-0.786)$ followed by stomata length (0.714) and stomata width (0.764) whereas; minimum ' $r$ ' value was observed in stomata frequency $(-0.230)$ which found negatively non significant with incubation period.

\section{Introduction}

Historically, stomata have been considered as passive portal of entry for plant pathogenic bacteria. However, recent studies suggest that stomata can play an active role in restricting bacterial invasion as part of the plant innate immune system. Some plant pathogens have evolved specific virulence factors to overcome stomata-based defense. Interestingly, many bacterial disease outbreaks require high humidity, rain, or frost damage, which could promote stomata opening and/or bypass stomata defense by creating wounds as alternative entry sites. Microbial entry into host tissue is a critical first step in causing 
infection in plants. In plants, it has been assumed that microscopic surface openings, such as stomata, serve as passive ports of bacterial entry during infection. The attachment of $X$. citri to plant cell surfaces is essential for its pathogenesis. Bacteria grow and persist as epiphytes, forming bio films on the host surface prior to endophytic colonization of the mesophyll tissue through natural openings, such as stomata, or through wounds

Xanthomonas citri pv. citri naturally penetrates the host tissues through stomata, hydathodes, lenticels or wounds (Bock et al., 2010., Gottwald and Graham 1992., Graham et al.,1992., Schubert et al., 2001.). Plant pathogenic bacteria are known to enter mainly through stomata; it is important entrance points for large number of plant pathogenic bacteria (Hung, 1998).

However, some evidence indicates that there is little relationship between the variability in susceptibility to citrus bacterial canker and the morphology or frequency of stomata on the leaf (Graham et al.,1992), suggesting that resistance is mostly due to differences in bacterial growth after access to the leaf. However, recent studies have indicated that stomata morphological characteristics or other external characters might play a role in infection (Favaro et al., 2014. Yin et al., 2011). As part of the plant innate immune system; stomata plays an active role in limiting bacterial invasion (Meletto et al., 2008). Information on stomata characteristics of different acid lime varieties will help to provide further information about this potentially important aspect of host defense.

The aim of present study was to study and compare the resistance of different varieties of acid lime to acid lime bacterial canker by screening against Xanthomonas axonopodis pv. citri, as well as to investigate the morphological characteristics of the stomata in relation to the varietal resistance to acid lime bacterial canker.

\section{Materials and Methods}

\section{Plant host assay for defense mechanisms}

\section{Screening of acid lime clones against} bacterial canker

The acid lime varieties Sai sarbati, Vikram, Pramalini, Phule Sarbati, NRCC-7 and NRCC-8 were collected from central nursery scheme, VNMKV Parbhani.

Screening tests were conducted on one year old acid lime seedlings of the above said clones under green house conditions. The seedlings free from infection were selected and inoculated by spraying the bacterial inoculum at 10 am for three consecutive days. Suitable controls were maintained without spraying the inoculum. The experiment was conducted using design CRD with tree replications. Data for disease severity were recorded and was scored using 0-4 scale (Table A). Per cent disease index was calculated all the verities using the following formula (Wheeler, 1969).

Percent Disease Index (PDI)

$$
=\frac{\mathrm{\Sigma xi}}{\mathrm{Xt} \times \mathrm{Gm}} \times 100
$$

Here, $\Sigma X \mathrm{X}=$ sum of individual disease rating, $\mathrm{Xt}=$ total number of leaf examined and $\mathrm{Gm}=$ maximum grade.

Based on PDI the varietal resistance was classified as described in Table no. 1.

\section{Anatomical bases of disease resistance/susceptibility}

The leaves of acid lime varieties viz., Sai sarbati, Vikram, Pramalini, Phule Sarbati, NRCC-7 and NRCC-8 were collected from 
central nursery scheme, VNMKV Parbhani and studied in vitro for stomata shape, stomata frequency, stomata size (length and width) and pore size. Images were taken by using 400 and 1000 magnifications per $(\mathrm{mm})$ microscopic field and further measurements were taken by using Image-J software.

\section{Stomata count}

Fevicol method was employed to record mean stomata number. Fevicol was smeared on both the surfaces of leaf to form a thin film. After five minutes fevicol layer was peeled off and mounted on clean glass slide and observed under microscope. Number of stomata on both surfaces were recorded at 400 magnifications and expressed in terms of number of stomata per microscopic field $(\mathrm{mm})$ area of leaf surface (Tanuja et al., 2016).

\section{Stomata size}

The slides prepared for stomata count was observed to measure the stomata size(length and width) and stomata pore size by using 400 and 1000 magnifications and further measurements were taken by using Image-J software and expressed in $\mu \mathrm{m}$ (Tanuja et al., 2016).

\section{Plant host assay for defense mechanisms}

Screening of acid lime cultivars against bacterial canker

Six varieties of acid lime were evaluated for the bacterial canker disease by pot culture technique under screen house conditions. All the varieties showed different levels of disease index and incubation period as shown in the Table No. 2.

Results (Table 2, Fig. 1) revealed that, average per cent disease index significantly varied from 13.50 to 28.50 . However, the maximum per cent disease index scored on variety Sai sarbati (28.50) followed by Pramlini (25.00), Vikram (21.75), Phule sarbati (21.50) and NRCC-8(19.50) while minimum per cent disease index scored on NRCC-7 (13.50).

Significant variation in incubation period was observed among these verities However, maximum incubation period was in variety NRCC-7 (16.75) followed by NRCC-8 (14.25), Phule sarbati (13.00), Pramalini (8.75) while minimum incubation period was observed in Sai sarbati (8.25).

Data recorded on disease reaction of different varieties revealed that, Sai sarbati and Pramalini showed susceptible response against the disease while Vikram, Phule sarbati, NRCC-7 and NRCC-8 were moderately resistant against the $X$. axonopodis pv. citri causing bacterial canker.

\section{Anatomical bases of disease resistance/susceptibility}

The leaves of acid lime varieties viz., Sai sarbati, Vikram, Pramalini, Phule Sarbati, NRCC-7 and NRCC-8 were studied in vitro for stomatal shape, stomatal frequency, stomatal size (length and width) and pore size.

Images were taken by using 100 and 1000 magnifications per microscopic field $(1.8 \mathrm{~mm}$ and $0.18 \mathrm{~mm}$, respectively) and further measurements were taken by using Image-J software.

Results (Table 3, Fig. 2) revealed that, shape stomata of all six verities were slightly oval to oval in nature. However, two of them viz., Sai sarbati and NRCC-7 were showing slightly oval shaped stomata while stomata of rest varieties viz., Vikram, Pramalini, Phule Sarbati and NRCC-8 were oval. 
Table.1 Disease rating scale

\begin{tabular}{|c|c|c|c|}
\hline Scale & Grade (Per cent leaf area covered) & \multicolumn{2}{|c|}{ Reaction } \\
\hline $\mathbf{0}$ & No infection & Resistant & $\mathrm{R}$ \\
\hline $\mathbf{1}$ & Trace to $10 \%$ & Moderately resistant & MR \\
\hline $\mathbf{2}$ & $11-25 \%$ & & \\
\hline $\mathbf{3}$ & $26-50 \%$ & Susceptible & S \\
\hline $\mathbf{4}$ & More than $50 \%$ & Highly susceptible & HS \\
\hline
\end{tabular}

(Gopi et al. 2012)

Table.2 Varietal screening of acid lime against $X$. axonopodis pv citri

\begin{tabular}{|c|c|c|c|c|}
\hline $\begin{array}{l}\text { Tr. } \\
\text { No. }\end{array}$ & Variety name & $\begin{array}{l}\text { Percent Disease Index } \\
\text { (PDI) }\end{array}$ & $\begin{array}{c}\text { Incubation period } \\
\text { (DAI) }\end{array}$ & Disease reaction \\
\hline $\mathbf{V}_{1}$ & Sai sarbati & $\begin{array}{c}28.50 \\
(32.25)\end{array}$ & 08.25 & $S$ \\
\hline $\mathbf{V}_{2}$ & Vikram & $\begin{array}{l}21.75 \\
(27.78)\end{array}$ & 10.50 & MR \\
\hline $\mathbf{V}_{3}$ & Pramalini & $\begin{array}{c}25.00 \\
(29.98)\end{array}$ & 08.75 & $S$ \\
\hline $\mathbf{V}_{4}$ & Phule sarbati & $\begin{array}{c}21.50 \\
(27.60)\end{array}$ & 13.00 & MR \\
\hline $\mathbf{V}_{5}$ & NRCC-7 & $\begin{array}{l}13.50 \\
(21.53)\end{array}$ & 16.75 & MR \\
\hline$V_{6}$ & NRCC-8 & $\begin{array}{l}19.50 \\
(26.18)\end{array}$ & 14.25 & MR \\
\hline \multicolumn{2}{|r|}{ S.E. \pm} & 0.55 & 0.33 & \\
\hline \multicolumn{2}{|c|}{ C.D. $(P=0.01)$} & 1.17 & 1.00 & \\
\hline
\end{tabular}

Table.3 Leaf anatomical study of different acid lime varieties

\begin{tabular}{|c|c|c|c|c|c|c|}
\hline \multirow[t]{2}{*}{$\begin{array}{l}\text { Sr. } \\
\text { No. }\end{array}$} & \multirow[t]{2}{*}{ Variety } & \multirow[t]{2}{*}{ Shape } & \multirow{2}{*}{$\begin{array}{c}\text { Avg. Stomatal } \\
\text { frequency* } \\
\text { Abaxial }\end{array}$} & \multicolumn{2}{|c|}{$\begin{array}{l}\text { Stomatal Size } \\
(\mu \mathrm{m}) *\end{array}$} & \multirow[t]{2}{*}{$\begin{array}{c}\text { Pore size } \\
(\mu \mathrm{m})^{*}\end{array}$} \\
\hline & & & & Length & Width & \\
\hline 1 & Sai sarbati & Slight oval & $\begin{array}{l}235.75 \\
(15.38)\end{array}$ & $\begin{array}{l}22.00 \\
(4.79)\end{array}$ & $\begin{array}{l}18.00 \\
(4.30)\end{array}$ & $\begin{array}{l}4.00 \\
(2.23)\end{array}$ \\
\hline 2 & Vikram & Oval & $\begin{array}{l}242.00 \\
(15.58)\end{array}$ & $\begin{array}{l}19.00 \\
(4.46)\end{array}$ & $\begin{array}{l}13.50 \\
(3.74)\end{array}$ & $\begin{array}{c}3.00 \\
(1.99)\end{array}$ \\
\hline 3 & Pramalini & Oval & $\begin{array}{l}175.25 \\
(13.27)\end{array}$ & $\begin{array}{l}25.00 \\
(5.09)\end{array}$ & $\begin{array}{l}16.00 \\
(4.06)\end{array}$ & $\begin{array}{l}4.00 \\
(2.23)\end{array}$ \\
\hline 4 & Phule Sarbati & Oval & $\begin{array}{l}182.00 \\
(13.52)\end{array}$ & $\begin{array}{l}20.00 \\
(4.58)\end{array}$ & $\begin{array}{l}15.00 \\
(3.94)\end{array}$ & $\begin{array}{l}3.00 \\
(1.99)\end{array}$ \\
\hline 5 & NRCC-7 & Slight oval & $\begin{array}{l}195.75 \\
(14.02)\end{array}$ & $\begin{array}{l}14.00 \\
(3.86)\end{array}$ & $\begin{array}{l}10.00 \\
(3.24)\end{array}$ & $\begin{array}{c}2.00 \\
(1.72)\end{array}$ \\
\hline 6 & NRCC-8 & Oval & $\begin{array}{l}219.00 \\
(14.83)\end{array}$ & $\begin{array}{l}19.00 \\
(4.45)\end{array}$ & $\begin{array}{l}16.00 \\
(4.06)\end{array}$ & $\begin{array}{c}3.00 \\
(1.99)\end{array}$ \\
\hline \multicolumn{3}{|c|}{ S.E. \pm} & 0.03 & 0.13 & 0.10 & 0.06 \\
\hline \multicolumn{3}{|c|}{ C.D. $(P=0.01)$} & 0.11 & 0.39 & 0.30 & 0.19 \\
\hline
\end{tabular}


Table.4 Correlation coefficient estimates between stomata factors and per cent disease index / incubation period

\begin{tabular}{|c|c|c|c|c|c|c|}
\hline & $\begin{array}{c}\text { Stomatal } \\
\text { frequency }\end{array}$ & $\begin{array}{c}\text { Stomatal } \\
\text { Pore size }\end{array}$ & $\begin{array}{c}\text { Stomatal } \\
\text { Length }\end{array}$ & $\begin{array}{c}\text { Stomatal } \\
\text { Width }\end{array}$ & PDI & $\begin{array}{c}\text { Incubation } \\
\text { period }\end{array}$ \\
\hline $\begin{array}{c}\text { Stomatal } \\
\text { frequency }\end{array}$ & 1.000 & 0.056 & -0.140 & 0.159 & $0.230^{\mathrm{NS}}$ & $-0.230^{\mathrm{NS}}$ \\
\hline $\begin{array}{c}\text { Stomatal Pore } \\
\text { size }\end{array}$ & 1.000 & 0.906 & 0.850 & $0.768^{* *}$ & $-0.786^{* *}$ \\
\hline $\begin{array}{c}\text { Stomatal } \\
\text { Length }\end{array}$ & & 1.000 & 0.825 & $0.714^{* *}$ & $-0.750^{* *}$ \\
\hline $\begin{array}{l}\text { Stomatal } \\
\text { Width }\end{array}$ & & & 1.000 & $0.764^{* *}$ & $-0.660^{* *}$ \\
\hline $\begin{array}{l}\text { ** Significant at 1\% level, } \\
\mathbf{0 . 2 8 8}\end{array}$ & & & Table value- at 1\% $\mathbf{0 . 3 7 2}$ at 5\% & \\
\hline
\end{tabular}

Plate.1 Microphotographs: Stomatal size of different acid lime cultivars (1000x)
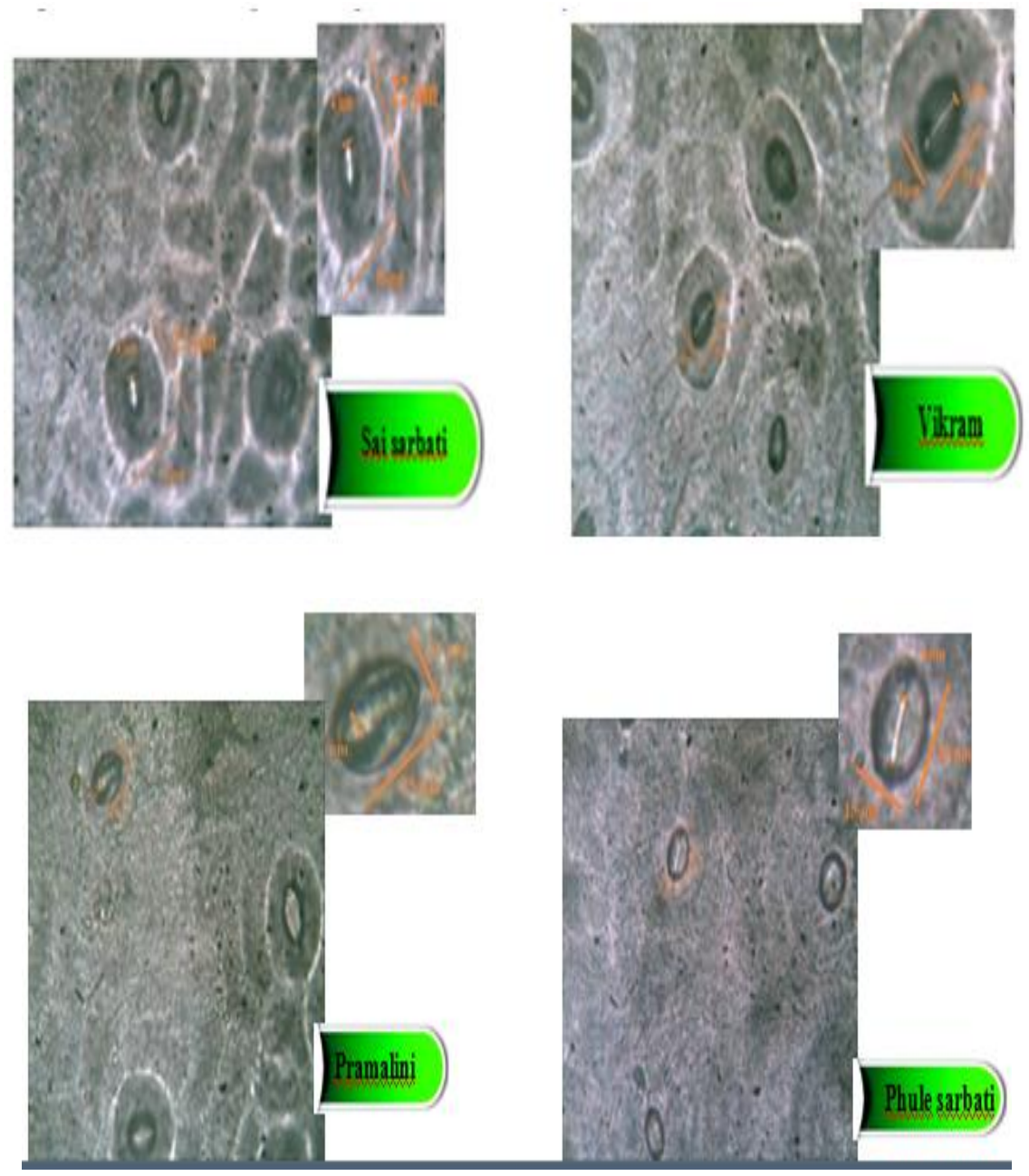

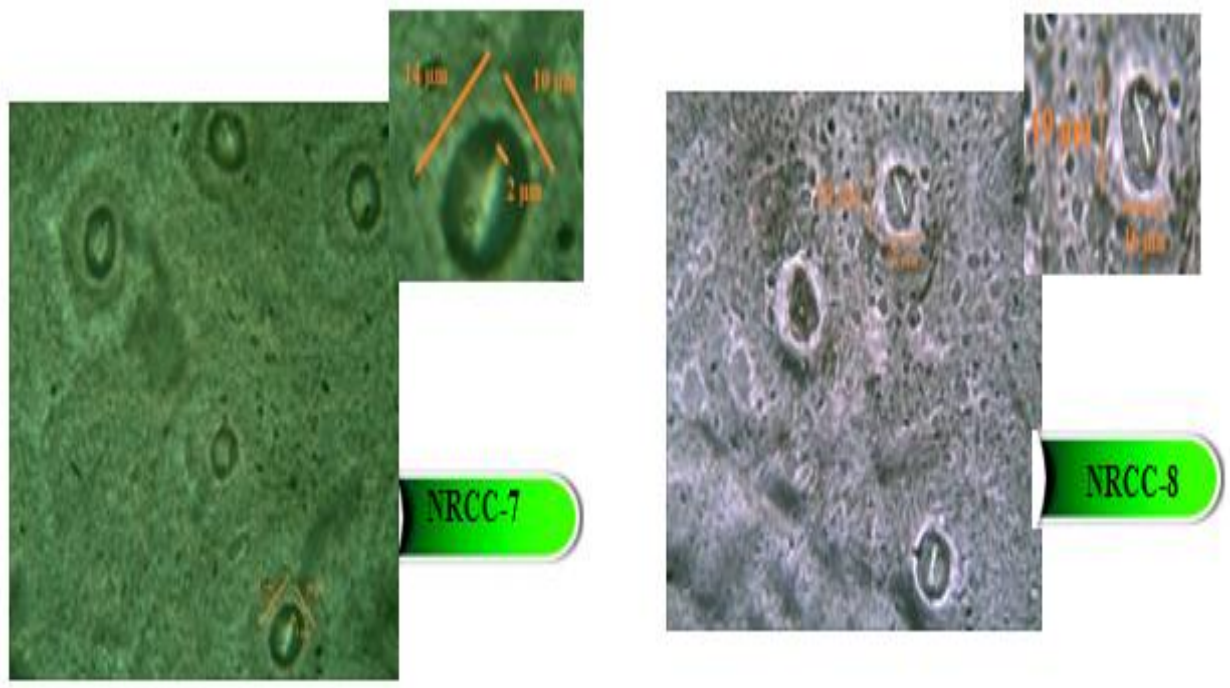

Plate.2 Microphotographs: Stomatal frequency of different acid lime cultivars (100x)
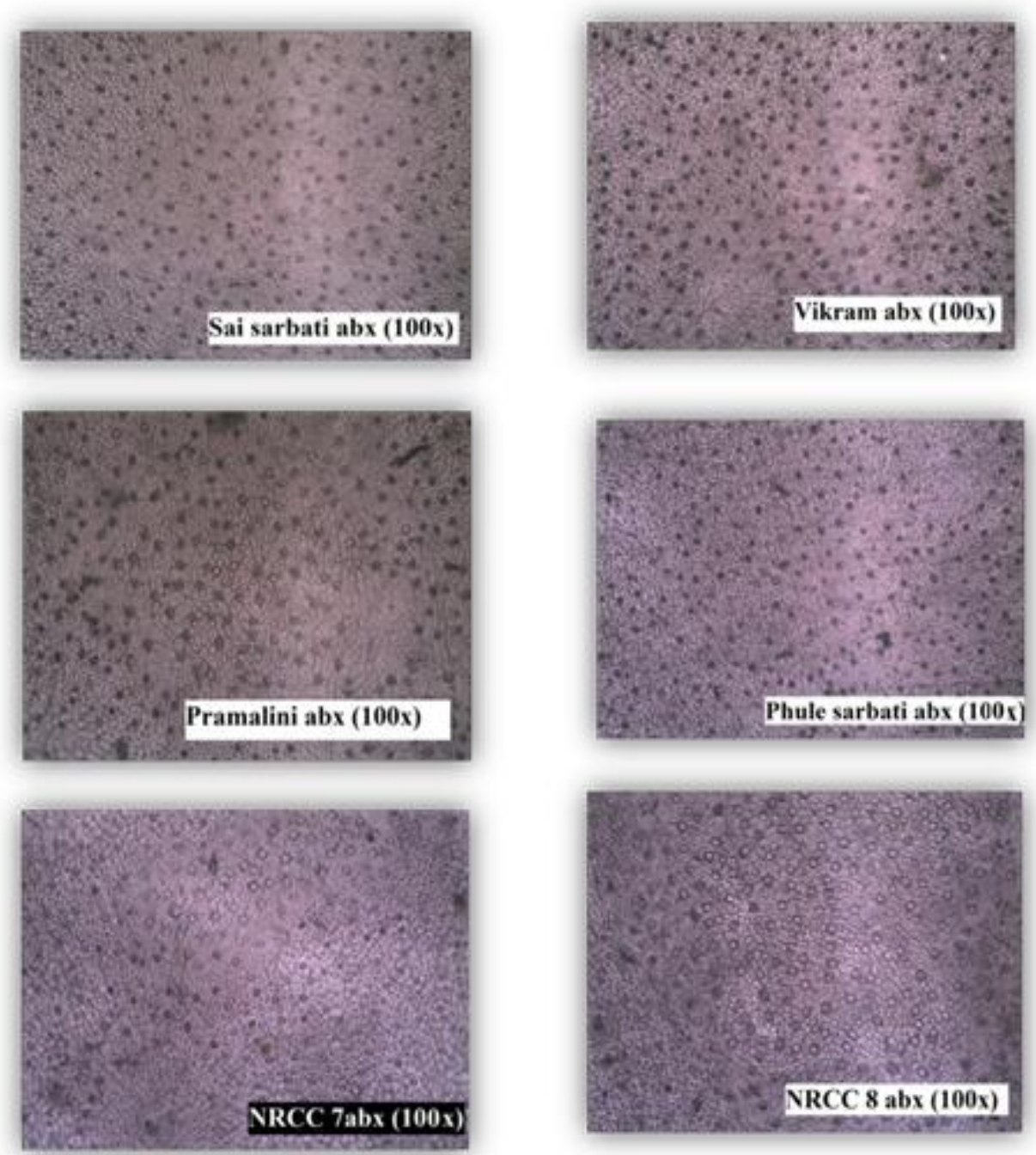
Fig.1

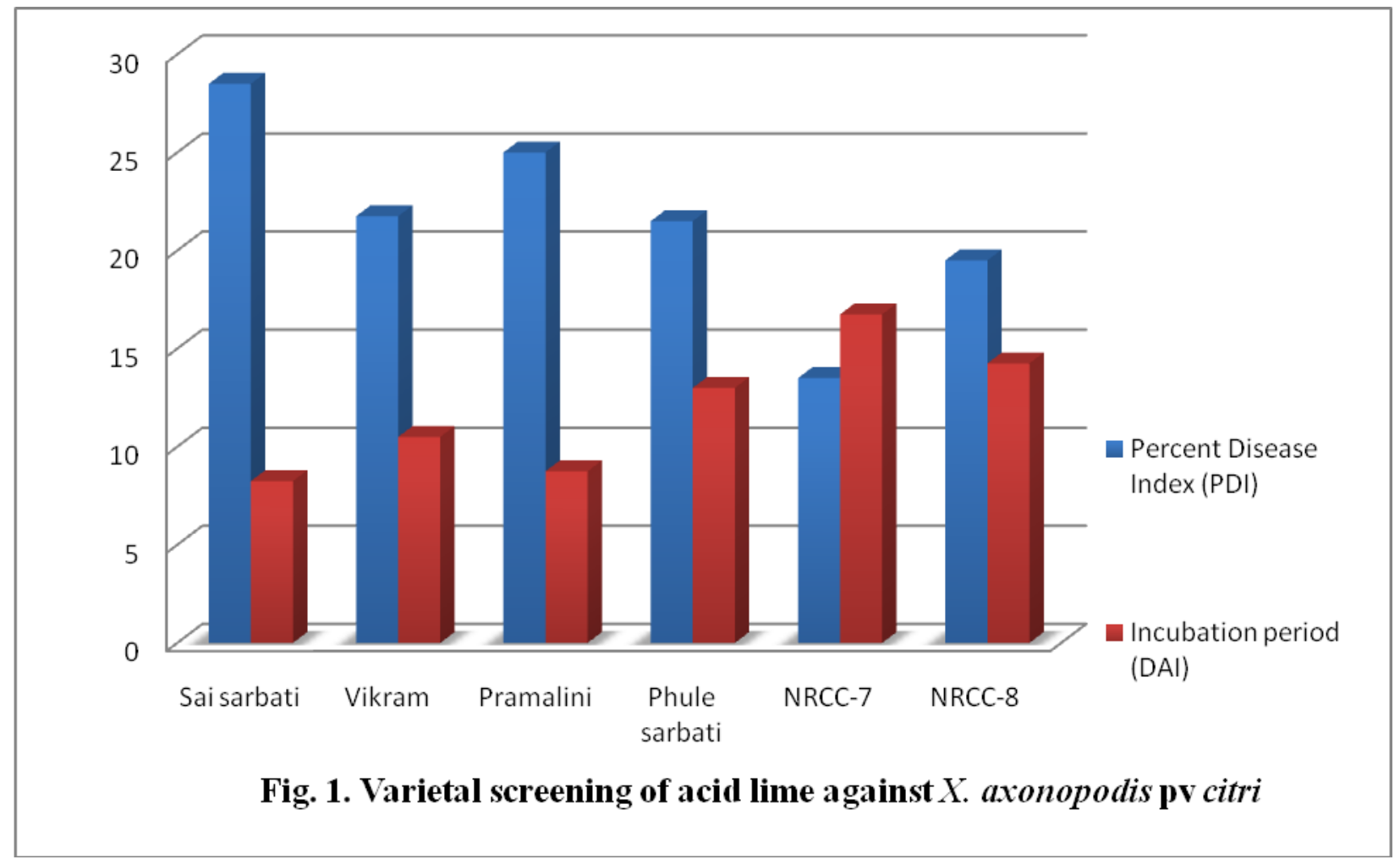

Fig.2

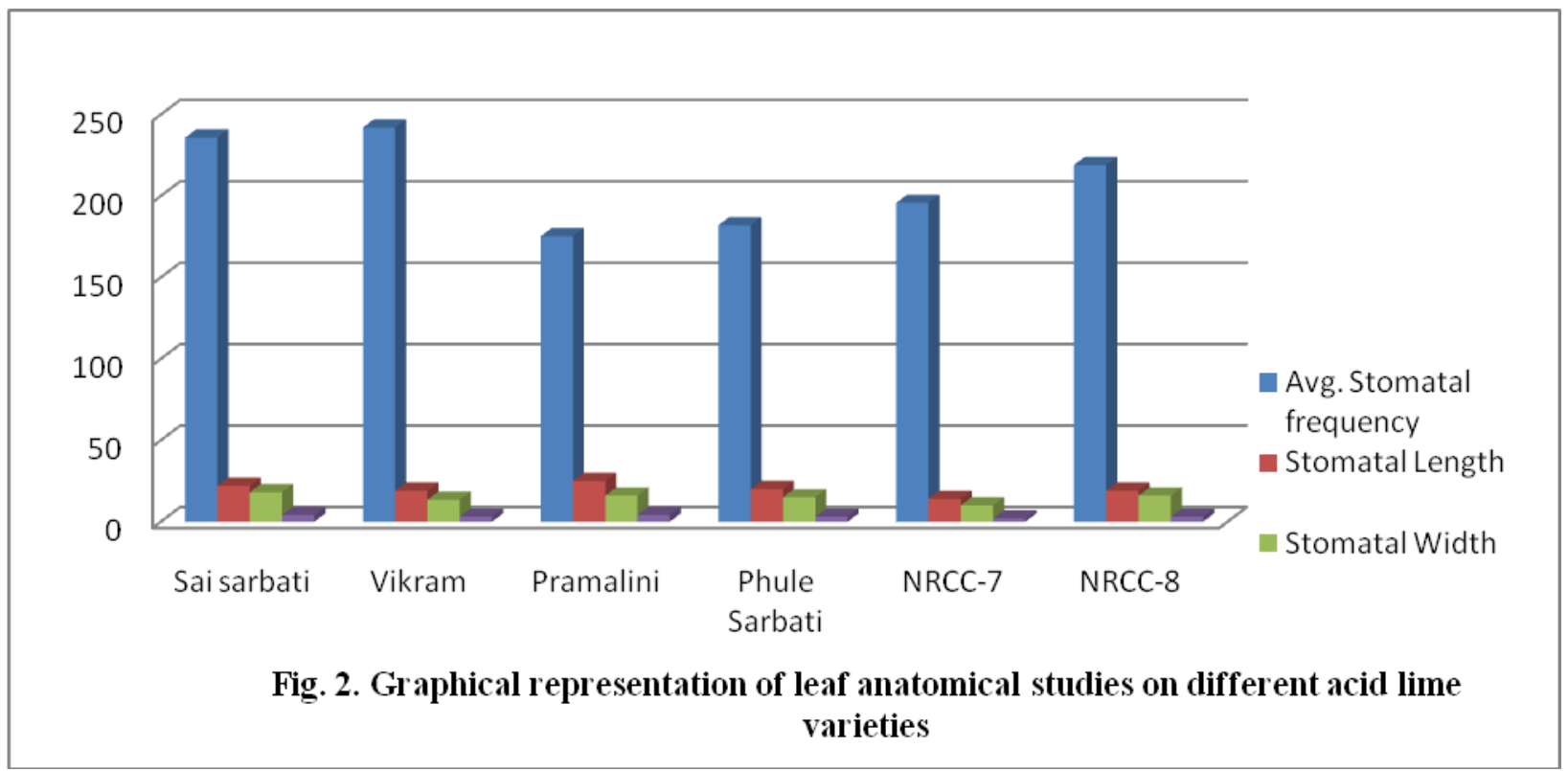

Average leaf stomata frequency varied significantly from 175.25 to 275.25 However, maximum stomata frequency was found in variety Vikram (242.00), followed by Sai sarbati (235.75), NRCC-8 (219.00), NRCC-7 (195.75) and Phule Sarbati (182.00) while 
minimum was in Pamalini (175.25). Significant variations in stomata length were found. However, maximum length of stomata was found in variety Pramalini $(25.00 \mu \mathrm{m})$ followed by Sai sarbati $(22.00 \mu \mathrm{m})$, Phule Sarbati $(20.00 \mu \mathrm{m})$ while in two verities Vikram,NRCC-8 recorded same stomata length i.e. $19.00 \mu \mathrm{m}$. The variety NRCC-7 showed minimum length of stomata (14.00 $\mu \mathrm{m})$. However, Maximum stomata width was found in variety Sai sarbati $(18.00 \mu \mathrm{m})$, followed by two varieties Pramalini and NRCC-8 which exhibited same stomata width i.e. $16.00 \mu \mathrm{m}$. The stomata width in Phule Sarbati was $15.00 \mu \mathrm{m}$. Minimum stomata width was recorded in variety NRCC-7 (10.00 $\mu \mathrm{m})$ which was followed by Vikram (13.50 $\mu \mathrm{m})$. Average stomata pore size in all verities was in the range $02.00 \mu \mathrm{m}$ to $04.00 \mu \mathrm{m}$. However, maximum stomata pore size was recorded by varieties Sai sarbati and Pramalini $(4.00 \mu \mathrm{m})$ followed by two varieties Vikram and NRCC-8 pore size i.e. $3.00 \mu \mathrm{m}$ while minimum pore size was found in variety NRCC-7 $(2.00 \mu \mathrm{m})$.

\section{Correlation coefficient estimates between stomata factors and per cent disease index / incubation period}

Correlations were estimated between stomata factors /characters and per cent disease intensity as well as incubation period. Stomata factors /characters like frequency pore size, length and width of all acid lime varieties (Sai sarbati, Vikram, Pramalini, Phule sarbati, NRCC-7 and NRCC-8) was taken in to consideration.

Results (Table 4) revealed that, highly significant correlations were observed between stomata factors with PDI. Correlation coefficient ranged between 0.230 to 0.768 for stomata characters and disease intensity. However, maximum ' $r$ ' value was observed in positive correlation between stomata pore size and per cent disease intensity (0.768) followed by stomata width (0.764) and stomata length (0.714) whereas; minimum ' $r$ ' value observed in stomata frequency (0.230) which found positively non significant with per cent disease intensity.

More or less similar trend was observed in correlation between stomata characters with incubation period. Highly significant but negative correlations were observed between stomata factors with incubation period. Correlation coefficient ranged between -0.230 to -0.786 for stomata characters and incubation period. However, maximum ' $r$ ' value was observed in negative correlation between stomata pore size and per cent disease intensity $(-0.786)$ followed by stomata length (0.714) and stomata width (0.764) whereas; minimum ' $r$ ' value was observed in stomata frequency $(-0.230)$ which found negatively non significant with incubation period.

Per cent disease intensity, as stomata pore size, stomata size and stomata frequency increases percent disease intensity was increased and positive correlation was observed whereas; as regards with incubation period, as stomata pore size, stomata size and stomata frequency increases incubation period was increased and found negative correlation.

Correlation between structural, physiological characters and intensity of disease caused by Xanthomonas spp. was demonstrated earlier by many workers. Shukla and Ganopadyhaya (1981) studied the role of leaf stomata index and size of 12 cultivars of rice with varied disease reactions against bacterial blight disease. They reported significantly low stomata index in resistant and moderately resistant varieties as compared to susceptible varieties. Ramos and Volin (1987) reported an association between the frequency of stomata on adaxial and abaxial leaf surface and the 
number of leaf lesions per square $\mathrm{cm}$. developed 12 days after inoculation with $X$. compestries pv. vesicatoria cultivar flora dad found highest range of stomata $140-185 / \mathrm{mm}^{2}$ and 237-296 / $\mathrm{mm}^{2}$ of adaxial and abaxial surface, respectively and reported 9-12 leaf lesions $/ \mathrm{cm}^{2} 12$ days after inoculation. While the another cultivar PL 127826 DI having the lowest range of stomata $34-98 / \mathrm{mm}^{2}$ and 185230 on adaxial and abaxial surface, respectively and found 4-9 leaf lesion. Melotto et al., (2008) studied the role of stomata in plant innate immunity and foliar bacterial diseases and reported that stomata can play an active role in limiting bacterial invasion as part of the plant innate immune system.

\section{References}

Beheshti B., Sharifi-Sirchi, G. R., Mansouri, M., Hosseinipour, A. and Schlaich, N. L. (2011). Resistance to citrus canker in key/Mexican lime induced by $\beta$ aminobutyric acid and green tea. American J. Agril. Biol. Sci. 6 (2): 242-248.

Bock, C.H., Graham, J.H., Gottwald, T.R., Cook, A.Z., Parker, P.E. (2010). Wind speed and wind-associated leaf injury affect severity of citrus canker on Swingle citrumelo. Europe J. Pl. Path., Wageningen, $128: 21-38$,

Civerolo, E. L. (1984). Bacterial canker disease of citrus. J. Rio Grande Valley Hort. Soc. 37: 127-146.

Das, R., Mondal B., Mondal P., Khatua, D. C. and Mukherjee, N. (2014). Biological management of citrus canker on acid lime through Bacillus subtilis (S-12) in West Bengal. Indian. J.Biopest. 7: 3841.

Favaro, M.A., Micheloud, N.G., Roeschlin, R.A., Chiesa, M.A., Castagnaro, A.P., Vojnov, A.A., Gmitter Jr, F.G., Gadea, J., Rista, L.M., Gariglio, N.F., Marano, M.R. (2014). Surface barriers of mandarin 'Okitsu' leaves make a major contribution to canker disease resistance. Phytopath., Saint Paul. 104: 970-976.

Fawcett, H. S. and Jenings, A. E. (1993). Records of citrus canker from herbacium specimens of the genus Citrus in England and the United States. Phytopath. 23: 820-824.

Gopi, V., Kumar, R. P., Prasada, B. and Gopal, K. (2012). Biochemical changes in acid lime clones in response to bacterial canker disease (Xanthomonas axonopodis pv. citri). J. Pl. Dis. Sci. 7(2): 19.-196. citrus. Phytopath. 81: 802-809.

Gottwald, T. R., Graham, J. H. and Schubert, T. S. (2002). Citrus canker the pathogen and its impact. Plant Helth Progress. 812-01RV.

Gottwald, T. R., Graham, J. H., Civerolo, E. L., Barret, H. C. and Hearn, C. J. (1993). Differential host range reaction of citrus and citrus relatives to citrus canker and citrus bacterial spot determined by leaf measophyl susceptibility. Pl. Dis. 77: 1004-1009.

Gottwald, T.R.; Graham, J.H. (1992). A device for precise and nondisruptive stomatal inoculation of leaf tissue with bacterial pathogens. Phytopath., Saint Paul, 82: 930-935.

Graham, J.H., Gottwald, T.R., Riley, T.D., Achor, D. (1992). Penetration through leaf stomata and growth of strains of Xanthomonas campestris in citrus cultivars varying in susceptibility to bacterial diseases. Phytopath., Saint Paul, 82: 1319-1325.

Hasabi, V., Askari, H., Mehdi, A. S. and Zamanizadeh, H. (2014). Effect of amino acid application on induced resistance against citrus canker disease in lime plants. J. Pl. Prot. Res. 54: 144149.

Hung, J.S. (1986). Ultrastructure of bacterial 
penetration in plants. Ann. Rev. Phytopath., Palo Alto. 24: 141-157.

Melotto, M., William, U. and Sheng Y. H. (2008). Role of stomata in plant innate immunity and foliar bacterial diseases. Annu. Rev. Phytopath.46: 101-122.

Ramos, L. J. and Volin, R. B. (1987). Role of stomatal opening and frequency on infection of Lycopersicon spp. by Xanthomonas campestris pv. vesicatori. Phytopath. 77 (9) 13111317.

Schubert, T.S., Rizvi, S.A., Sun, X., Gottwald, T.R., Graham, J.H., Dixon, W.N. (2001) Meeting the challenge of eradicating citrus canker in FloridaAgain. Pl. Disease, Saint Paul, 85: 340-356.

Shukla, S. N. and Ganopadhaya, S. (1981). Stomatal index and size of stomatal opening of rice cultivars varying in reaction to bacterial leaf blight. Proc. Indian Nat. Sci. Acad. B47: 557-559.

Stall, R. E. and Civerolo, E. L. (1991). Research relating to the recent outbreak of citrus canker in Florida.
Ann. Rev. Phytopath. 29:399-420.

Tanuja, P. B., Murthy, B. N. S. and Jagannath, S. (2016). Role of stomatal frequency in plant innate immunity against bacterial blight disease of pomegranate. Int. J. Agric. Sci. Res. 6: 161-164.

Verniere, C., Hartung, J. S., Pruvost, O. P., Civerolo, E. L., Alvsrez, A. M., Maestri, P. and Luisetti, J. (1998). Characterization of phenotypically distinct strains of Xanthomonas axonopodis pv.citri. from South west Asia. European. J. Pl. Path. 104 (5): 477-487.

Wheeler, B.E.J. (1969). An introduction to plant diseases. John Willey and Sons Ltd. London. Pp. 374.

Yin. W., Fu, X. Z., Liu, J.H., Hong, N. (2011). Differential structure and physiological response to canker challenge between Meiwa kumquat and Newhall navel orange with contrasting resistance. Scien. Horti., Amsterdam, 128: 115123.

\section{How to cite this article:}

Jadhav, R. R., K. T. Apet and Kadam, D. S. 2020. Investigations on Role of Stomata in Development of Citrus Canker caused by Xanthomonas axonopodis pv. citri. Int.J.Curr.Microbiol.App.Sci. 9(12): 3497-3506. doi: https://doi.org/10.20546/ijcmas.2020.912.415 